\title{
MOLITVA O IZBAVLENII OT BLUDA V RUKOPISU KB 12/1089
}

\author{
Molitva o izbavlenii ot bluda in the Manuscript KB 12/1089
}

\author{
František Čajka
}

DOI: $10.17846 /$ CL.2018.11.1.105-118

\begin{abstract}
AJKA, František. Molitva o izbavlenii ot bluda in the Manuscript KB 12/1089. The study deals with the so far unexplored manuscript of a prayer called Molitva o izbavljenii otz bloda, which is preserved in the manuscript collection from the Kirillo-Belozersky Monastery (White Lake St. Cyril's Monastery). The text of the prayer is preserved in the manuscript KB 12/1089 (National Library of Russia, Saint-Petersburg) from the third quarter of the 16th century. The close relationship of known manuscript versions of the prayer contained in the manuscripts of Czech Church Slavonic Forty Gospel Homilies by Pope Gregory the Great (Besédy na evangelije) and in the ancient Euchologium Sinaiticum strongly reinforces the hypothesis about the Great Moravian origin of their common archetype. The aim of the study is to reveal the relationship of the newly registered text KB 12/1089 to familiar texts. An integral part of the study also deals with an edition of the prayer (KB 12/1089) and its critical apparatus based on the text of all known (edited) manuscripts of the prayer.
\end{abstract}

Keywords: Old Church Slavonic, Church Slavonic, paraliturgical texts, prayers

\begin{abstract}
Abstrakt: ČAJKA, František. Molitva o izbavlenii ot bluda v rukopise KB 12/1089. Štúdia sa zaoberá doteraz neskúmaným rukopisným znením modlitby označovanej ako Molitva o izbavljenii otz bloda, ktorá je zachovaná v rukopisnej zbierke Kirillo-bělozerského kláštora. Text modlitby sa zachoval v rukopise KB 12/1089 (Ruská národná knižnica, Sankt-Peterburg), ktorý pochádza z tretej štvrtiny 16. storočia. Blízky textový vztah známych rukopisných znení modlitby zachovaných v českocírkevnoslovanských Čtyríceti homiliích na evangelia papeže Řehoře Velikého (Besědy na evangelije) a v starobylom Sinajskom euchológiu silne podporujú hypotézu o velkomoravskom pôvodu spoločného archetypu Molitva o izbavljenii otz bloda. Cielom tejto štúdie je odhalit vztah medzi novo evidovaným textom KB 12/1089 a už známymi textami modlitby. Súčastou tejto štúdie je taktiež edícia textu modlitby zachované v rukopise KB 12/1089 a kritický aparát, ktorý je založený na texte všetkých známych (resp. editovaných) rukopisov.
\end{abstract}

Klúčové slová: staroslovienčina, cirkevná slovančina, paraliturgické texty, modlitby

Paraliturgické texty modlitební povahy označované jako Molitva o izbavljenii otz bloda („Modlitba za čistotu“) a Slovo bolęštiich r radi („Slovo za nemocné“) představují texty, v jejichž případě nebyla zjištěna řecká či latinská předloha. Je také možné, že představují texty originální. Oba texty byly dosud známy jednak ve znění Euchologia sinajského, starobylého rukopisu kanonické staroslověnštiny, jednak v rukopisech Besěd na evangelije, českocírkevněslovanské památky zachované $\mathrm{v}$ opisech v ruském prostředí. Běsědy na evangelije mají oba paraliturgické texty zapsány v podobě pevné součásti svého textu, resp. jako př́lohy těsně navazující na vlastní homiletický text. To vedlo některé autory k logickému závěru, že Molitva o izbavljenii otz bloda a Slovo bolęštiich r radi 
představují nejspíše texty velkomoravské, tradované v prostředí přemyslovských Čech $10 .-11$. století, z něhož se jako nedílná součást rukopisů Besěd na evangelije dostaly na Rus. ${ }^{1}$

Podstatné novum do studia problematiky přineslo zjištění dalších rukopisných záznamů ruského původu, a to z kodexů neobsahujících text Besěd na evangelije. ${ }^{2}$ Tím se okruh známých textů rozšíril natolik, že bylo možné objasnit základní textologicky relevantní vztahy mezi třemi skupinami zachovaných textů, a to podle znění Euchologia sinajského, rukopisů Besěd na evangelije a samostatných zápisů ruské provenience ve sbornících různého charakteru. ${ }^{3}$ Srovnávaný materiál přinesl zjištění, že je možné považovat za reálný předpoklad dvou blízkých znění Molitvy o izbavljenii otz bloda, reprezentovaných v zachované podobě rukopisy ruské provenience a zněním doloženým v Euchologiu sinajském. Obě textologické skupiny vycházejí ze společného archetypu. Dalším zjištěním bylo odhalení těsného vztahu samostatných „sborníkových“ zápisů Molitvy o izbavljenii otz bloda (a také Slova bolęštiichr radi) k těm rukopisům, jejichž obsahem jsou Besědy na evangelije. Filologicky nezkoumaným a dosud needitovaným textem modlitby podle znění rukopisu KB 12/1089 si tato studie uvedené závěry klade za cíl prověřit. V dalších částech této studie se tak soustředíme zejména na popis Molitvy o izbavljenii otı bloda a výklady o Slovu bolęštiichr radi ponecháme stranou.

\section{Rukopisná doložení Molitvy o izbavljenii otъ blǫda}

\section{Rukopisná tradice staroslověnská}

Hlaholicí psané Euchologium sinajské (Modlitebník sinajský, Euch) pochází ve svém rukopisném záznamu z 11. století. Obsahem památky jsou modlitby, penitenciál a „služebnik“ (liturgikon). Text Molitvy o izbavljenii otz bloda je v kodexu zapsán na foliích 36b 16 - 37a 20.

\section{Rukopisná tradice ruská}

Rukopisnou tradici Molitvy o izbavljenii otz bloda v ruském prostředí lze podle vztahu k textu Besěd na evangelije (tvoří nedílnou součást jejich textu či představují samostatné zápisy) i některých rysů textových formálně rozdělit na dvě skupiny.

První skupinu tvoří zápisy modlitby v rukopisech Besěd na evangelije (Čtyřiceti homilií na evangelia papeže Řehoře Velikého; dále Bes), které jsou překladem latinského homileticko-exegetického díla XL homiliarum in Evangelia libri duo papeže Řehoře Velikého „Dvojeslova“ (?540-604, ponti-

1 Mareš (2000b, 284), Vepřek (2008, 444), Vepřek (2010, 44), Vepřek (2014, 268-269), podobně Čajka $(2013,51)$. J. Reinhart se domnívá na základě neexistence obou textů v jedné z vývojových linií textové tradice Besěd na evangelije, která vychází z hyparchetypu Uvarovského rukopisu, že uvedené modlitby byly zařazeny do př́slušných kodexů až v ruském prostředí (Reinhart 2000,257). Stanovení definitivního závěru v této otázce přesahuje téma této studie, nicméně označení Molitvy o izbavljenii otr bloda jako „Modlitby sv. Ǩehoře“ ve sbornících se samostatnými zápisy modlitby (tj. bez textu Besěd na evangelije), ukazují na zřejmou souvislost tímto způsobem tradované linie modlitby se svým zdrojem (kodexy se zápisem Besěd na evangelije). Uvedený stav tak s největší pravděpodobností svědčí spíše pro přičlenění textu Molitvy o izbavljenii otz bloda (a také Slova bolęštiichr radi) již v českém prostředí.

Viz Čajka (2013).

Čajka $(2013,52)$.

4 Edice viz Nahtigal (1942), fototypické vydání Nahtigal (1941).

5 Edice viz Migne (1849), nověji v kritické edici Étaix (1999). 
fikát 590-604). Památka byla přeložena v přemyslovských Čechách 11. století, přičemž její vznik je možno nejpravděpodobněji spojovat s činností Sázavského kláštera (1032-1096/7). ${ }^{6}$

Text Bes byl zachován v ruském prostředí v šestnácti relativně úplných cyrilicí psaných rukopisech z 13. - 18. století, a dále také ve výtazích ze slovanského překladu. ${ }^{7}$ Doloženy jsou i citace textu Bes v jiných památkách, a to v traktátu „Власфимия“8, $\mathrm{v}$ Merilu pravedném či v některých dalších textech podobného okruhu? .

Jako dokladový materiál byl v dalších částech studie použit text Molitvy o izbavljenii otz bloda zapsaný v těch relativně úplných rukopisech (Pogod, Q, Synod), jejichž znění byla kompletně zaznamenána $\mathrm{v}$ Konzalově edici Bes. ${ }^{10} \mathrm{~K}$ srovnávané skupině rukopisů Bes připojujeme i materiál rukopisu Synod 992, který je součástí Velkých četjích minejí metropolity Makarije. ${ }^{11}$ Vymezená skupina rukopisů Bes představuje textologicky relevantní znění vycházející z hyparchetypu textologické skupiny rukopisu Pogodinského. ${ }^{12}$ Text Molitvy o izbavljenii otz bloda (a také Slova bolęštich r radi) uvedené rukopisy bud' připojují k vlastnímu homiletickému textu Řehoře Velikého (Pogod), nebo jej do něj včleňují jako 17. homilii (Q, Synod, Synod 992).

\begin{tabular}{|c|c|c|c|c|}
\hline označení & signatura & původ & datace & zápis \\
\hline Pogod & Погод 70 & ruskocsl. & 13. stol. & $328 b \beta 1-30$ \\
\hline Q & Q. I. 1202 & ruskocsl. & 14. stol. & $\begin{array}{l}111 b 23-112 a \\
24\end{array}$ \\
\hline Synod & Синод 47 & ruskocsl. & 17. stol. & $84 a 6-15$ \\
\hline Synod 992 & $\begin{array}{l}\text { Синод } 992 \\
\text { (П 789) }\end{array}$ & ruskocsl. & $\begin{array}{l}\text { 1. polovina } \\
\text { 16. stol. }\end{array}$ & $\begin{array}{l}235 c 26-235 d \\
17\end{array}$ \\
\hline
\end{tabular}

Druhou skupinu zápisů Molitvy o izbavlenii otz bloda ruského původu představují znění zachovaná $\mathrm{v}$ samostatných zápisech $\mathrm{v}$ různých typech sborníků. Novější bádání poukázalo zejména na ty zápisy modlitby, které byly součástí knižního fondu Trojicko-sergijevské lávry. ${ }^{13}$ Rukopisy obsahující př́islušná znění modlitby byly formou digitalizace zpřístupněny spoluprací Trojickosergijevské lávry a Ruské národní knihovny v Moskvě. V uvedené knihovně jsou taktéž uloženy, a to jako součást fondu s označením ф. 304.I. Číslo rukopisů, v nichž je samostatně zapsána

6 Český původ překladu, na nějž poprvé upozornil A. I. Sobolevskij (Sobolevskiy 1900, Sobolevskiy 1906, Sobolevskiy 1910) v jeho průkopnických pracích věnovaných velkomoravským a českocírkevněslovanským památkám, doložili F. V. Mareš a J. Reinhart; viz Mareš (1963), resp. Mareš (2000, 368-402) a Reinhart (1980). Kritickou edici Bes vydal ve dvou svazcích V. Konzal, viz Konzal (2005), Konzal (2006).

7 Přehled rukopisů viz Konzal (2005, XVI-XIX); k problematice výtahů z Bes viz Konzal (2005, XI a XIV), Konzal (2006, iii) a Zema $(2007,26)$.

8 Viz Alekseev $(2012,161,165)$, srov. též Temchin $(2016,475)$.

9 Viz Vershinin (2015a), Vershinin (2015b, 6), Vershinin (2017, 41-44).

10 Viz Konzal (2005), Konzal (2006). Základní popis rukopisů a literatury předmětu viz Konzal (2005, XII, XIV, XVI-XXI).

11 Edice viz Weiher et al. $(1998,470)$.

12 Viz Reinhart $(2000,286)$. Druhá vývojová linie rukopisné tradice Bes (méně početně zastoupená), vycházející z hyparchetypu Uvarovského rukopisu (Uvar 197), neobsahuje zápisy Molitvy o izbavljenii otz bloda či Slova bolęštiichs radi.

13 Viz Čajka (2013). 
Molitva o izbavlenii otz bloda zřetelným a přehledným zpơsobem odkazuje k číslu knihovnické signatury rukopisů uvedeného fondu. ${ }^{14}$

\begin{tabular}{|l|l|l|l|}
\hline označení & původ & datace & zápis \\
\hline TSL 277 & ruskocsl. & 16. stol. & 23b 15-24b 9 \\
\hline TSL 747 & ruskocsl. & 1445 & $\begin{array}{l}460 \mathrm{a} 16-461 \mathrm{a} \\
18\end{array}$ \\
\hline TSL 771 & ruskoscl. & 1524 & $338 \mathrm{a} 4-338 \mathrm{~b} 9$ \\
\hline
\end{tabular}

\section{Molitva o izbavljenii otъ blọda podle znění rukopisu KB 12/1089}

Další znění „Modlitby za čistotu“ obsahuje ruskocírkevněslovanský rukopis KB 12/1089, který pochází ze třetí čtvrtiny 16 . století. ${ }^{15}$ Rukopis o rozsahu 238 listů velikosti $14.5 \times 10 \mathrm{~cm}$ byl dříve součástí majetku Kyrillo-Bělozerského kláštera. V současnosti je rukopis součástí fondu (ф. № 351) kirillo-bělozerské sbírky Ruské národní knihovny (Русская национальная библиотека, РНБ) v Petrohradě, kde je uložen pod signaturou КБ 12/1089. ${ }^{16}$ Jelikož jsou součástí kodexu zejména homiletické texty církevních otců (sv. Basileia Velikého, sv. Jana Zlatoústého, sv. Efréma Syrského aj.), výpisky z dalších textů podobného charakteru (z díla Makaria Velikého, pateriku aj.) a životy (sv. Marka a sv. Pajsije Velikého: Житие и жизнь преподобнаго отца нашего Марка Афинеискаго, Житие Паисия Великого), v popisech rukopisu je sborník z typologicko-obsahové stránky charakterizován jako „сборник религиозно-нравоучительного содержания“17 с̌i „сборник аскетический“18.

Text modlitby je zapsán poluustavem v jednom sloupci na fol. 141b 23 - 142a 23 s odkazem na autorství papeže Řehoře Velikého s incipitem Молитва святаго Григориа папы римьскаго о избавлении блуда и о угашении плоти.

14 K popisu rukopisů TSL 277, TSL 747 a TSL 771 a další literatuře předmětu souhrnně viz Čajka $(2013,45$ 46). Součástí rukopisných fondů Trojicko-sergijevské lávry byly i tři další (dosud needitované) rukopisy modlitby (TSL 232, TSL 262, TSL 315), které jsou součástí rozsáhlejších liturgických textů, srov. Čajka $(2013,45)$. Z dalších needitovaných rukopisů je nutno zmínit (vedle rukopisu, jemuž je věnován tento př́íspěvek) také rukopis č. 92 Tolstovovy sbírky o 279 listech, psaný poluustavem, který pochází ze 17. století, srov. Stroyev (1827, 62-64). Na fol. 192 - 194 je zapsán text modlitby s označením Молитва св. Григорia, Папы Римскаго: о избавленіи блуда, и о угашеніи плоти, и о сохраненіи зрака блуднаго отъ помышленіа ложна (sic), и о пріятіи всякаго дара спасеннаго.

15 Popis rukopisu viz Yegorova (2004, 218-221), Opis f. 351 (1985, 337) - zde je rukopis datován do 16. století, srov. též Čajka $(2013,50)$.

16 Děkuji Ruské národní knihovně v Petrohradu, oddělení rukopisů, za laskavé zhotovení fotokopií textu „Modlitby za čistotu“ podle rukopisu KB 12/1089 a za fotokopii strojopisu popisu rukopisů fondu č. 351, viz Opis f. 351 (1985).

17 Viz Opis f. $351(1985,337)$.

18 Viz Yegorova $(2004,218)$. 


\section{Edice}

Součástí představené edice je text Molitvy o izbavljenii otz bloda podle znění rukopisu KB 12/1089 (fol. 141b 23 - 142a 23), který je opatřen po levé straně číselnými údaji o řádcích, resp. odkazy na prríslušné místo folia, na němž je text zapsán. Kritický aparát zachycuje z vymezené skupiny rukopisných zápisů modlitby (Euch, Pogod, Q, Synod, Synod 992, TSL 277, TSL 747 a TSL 771) různočtení ke znění rukopisu KB 12/1089. Tato různočtení jsou uváděna v textu po jednoduché skobě (]). Z důvodu přehlednosti dokladového materiálu uvádíme $\mathrm{v}$ př́padě shodných textologických variant s rukopisem KB 12/1089 odkaz na příslušné rukopisy v kulaté závorce za rovnítkem,

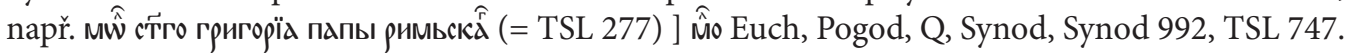
Jazykem poznámkového aparátu je latina.

Fragmentárně zachované znění rukopisu Pogod (část $\mathrm{A})^{19}$ se v dokladovém materiálu různo-

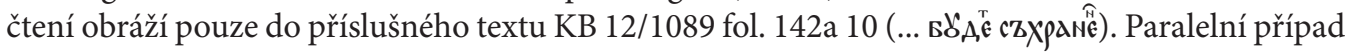
zápisu pouze druhé části modlitby (část B) od uvedené sekvence do konce textu představuje rukopisné znění TSL 771.

\section{KB 12/1089}

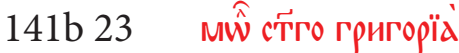

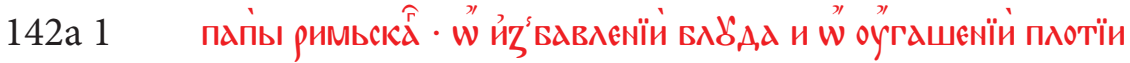

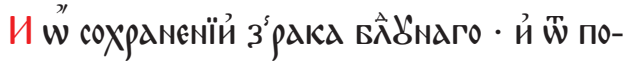

мьшлєкїа сложна · й wै прїа’тїи

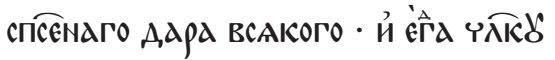

5

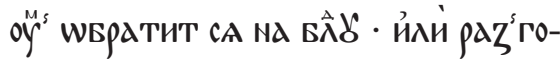

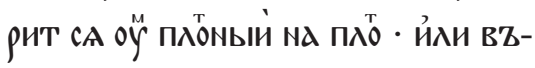

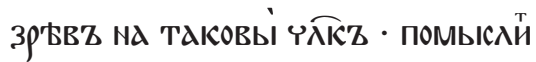

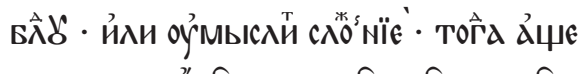

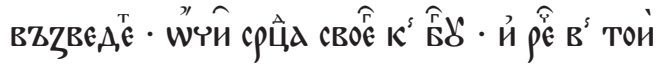

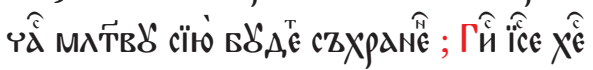

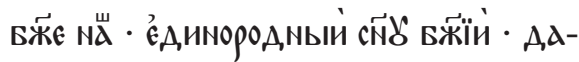

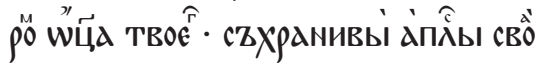

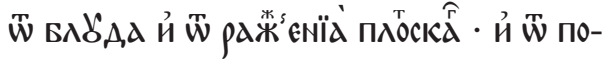
мьшлємїа БлلٌА,

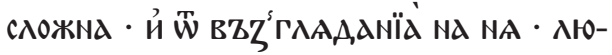

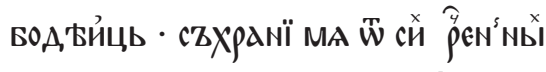

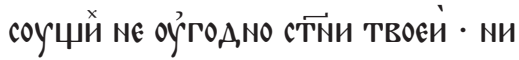

19 Viz kapitola Rozsah zachovaného textu. 


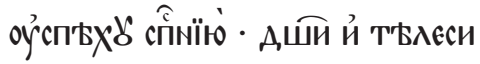

мое́м' · й

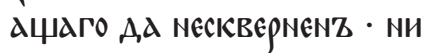

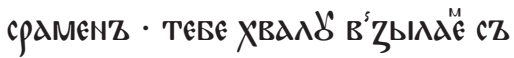

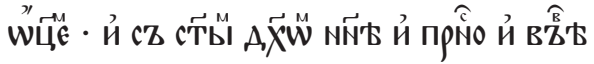

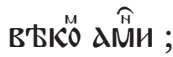

\section{Textové varianty}

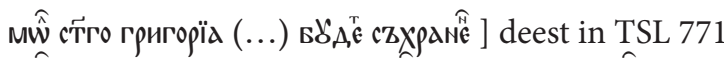

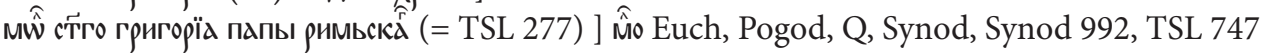

w из Бавлєнїи БлбА, (= Euch, Q, Synod, Synod 992, TSL 277, TSL 747) ] w зБавлєнии [и] $\widetilde{w}$ влоу,a, Pogod ${ }^{20}$

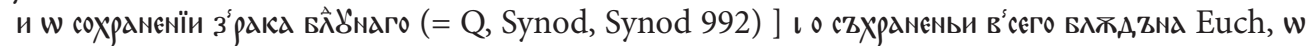
схранении зрака влоудьнаго Pogod, и ш съхраненїи ш з зрака влоуннаго TSL 277, TSL 747

и ш̈ помышлєнїа сложна (= Pogod, Q, Synod, Synod 992, TSL 277, TSL 747) ] deest in Euch

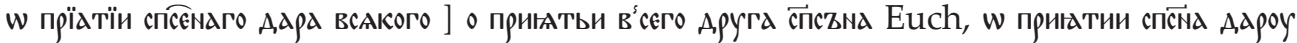

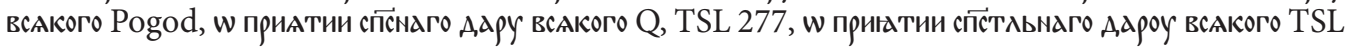
747, W ПрИатТ̈̈а спасенаго адроу всакого Synod, Synod 992

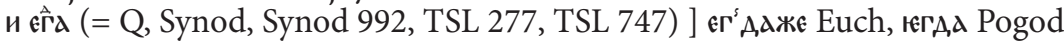

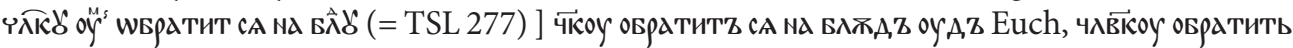
са оум'z na влоуда Pogod, Q, Synod, Synod 992, TSL 747

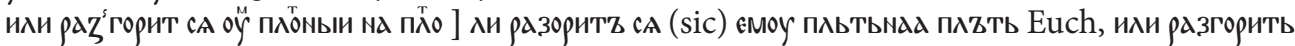

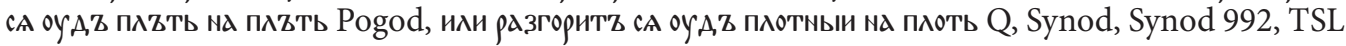
277, иАи разгориТЬ СА ОУАZ ПАОТнЫ на ПАОТны TSL 747

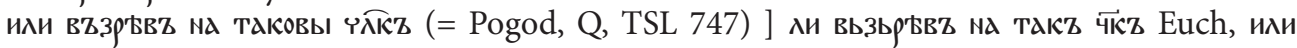
возр'БвZ на каковыи челов'Вкъ Synod, Synod 992, TSL 277

помыслй Бйلे (= Pogod, Q, TSL 277) ] пом'іслитъ на Блждъ Euch, Synod, Synod 992, помыслить и БАӧу TSL 747

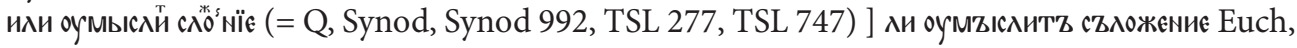
Pogod

шчи срцих свое́์ (= Pogod, Q, Synod, Synod 992, TSL 277, TSL 747) ] очи срцц си Euch в тои ча́ (= Synod, Synod 992, TSL 277, TSL 747) ] въ тъ часъ Euch, Pogod, Q

мкт̈во̆ сїю (= Euch, TSL 747) ] сию молитвоу Pogod, Q, Synod, Synod 992, TSL 277

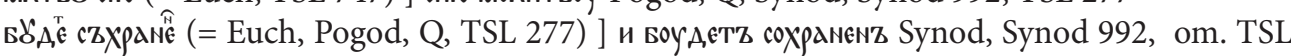
747

deest in KB 12/1089, Euch, Pogod, Q, Synod, Synod 992, TSL 277 ] мїтва стүго григорина папы

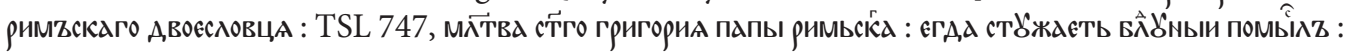
TSL 771

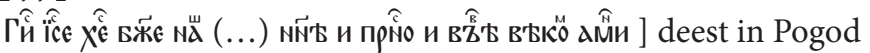

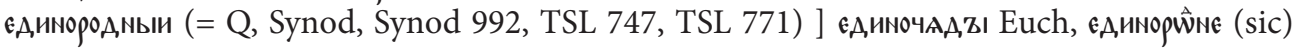

20 Zápis завдвлєнии považuje za hláskoslovný bohemismus F. V. Mareš (Mareš 1963, 422; Mareš 2000a, 372), srov. též Vepřek (2015). 


\section{TSL 277}

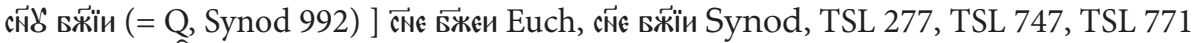

дарӧ шца твоє (= Euch, Q, Synod, Synod 992, TSL 747, TSL 771) ] ижє дарӧ ш̈ц̆а твоєго TSL 227 съхранивы (= Synod 992, TSL 747) ] сzхранеи Euch, схранивzыи Q, Synod, TSL 227, TSL 771 w

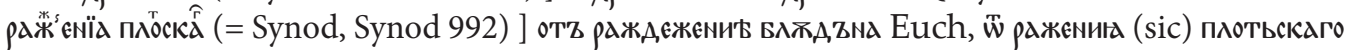

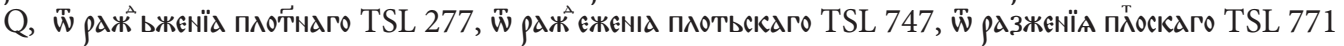
deest in KB 12/1089, Euch ] и ш̈ зрака влуданаго Q, Synod, Synod 992, TSL 277, TSL 747, TSL 771

влбада (= Q, Synod, Synod 992, TSL 277, TSL 747, TSL 771) ] влжатна Euch и оумышленїа сложна (= Q, Synod, Synod 992, TSL 277, TSL 747, TSL 771) ] deest in Euch

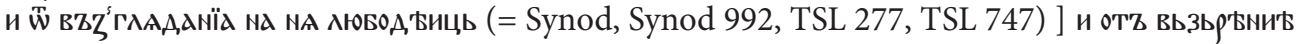

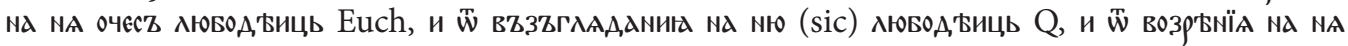
АюБОА,'ИЦЪ TSL 771

съХранї ма (= Q, Synod, Synod 992, TSL 277, TSL 747) ] съХрани ı ма Euch, съХрами гй и мене TSL 771

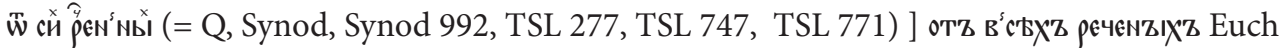
nе оугодно (= Q, Synod, Synod 992, TSL 277) ] вZ годинж Euch, nе оугодны TSL 747, и не OyгOA,NO TSL 771

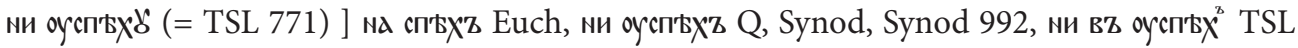
227, TSL 747

cกิ̀їю (Euch, Q, TSL 277, TSL 747, TSL 771) ] спасєеїє Synod, Synod 992

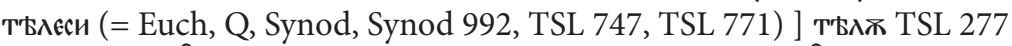

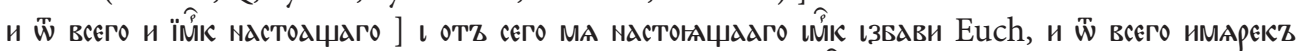

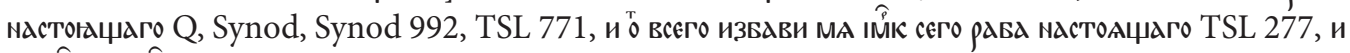
W̋ в в

ни сраменz (= Q, Synod, Synod 992, TSL 771) ] deest in Euch, ни посрамаєнъ TSL 277, ми сраміิє TSL 747

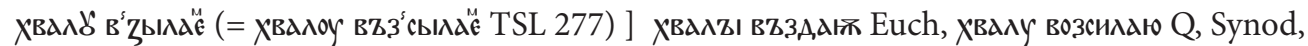
Synod 992, TSL 747, Хвалоу вZ3сылаємZ to TSL 771

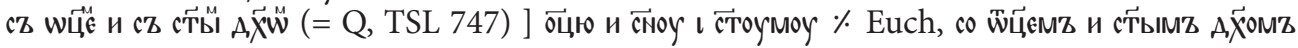
Synod, Synod 992, TSL 277, TSL 771

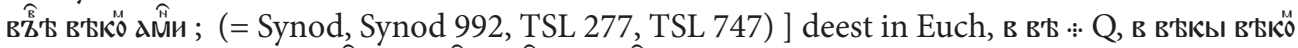

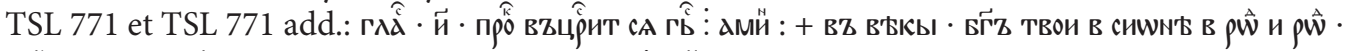

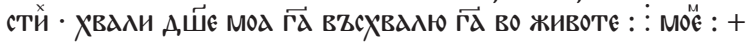

\section{Rozsah zachovaného textu}

Již v předešlých částech studie jsme poukázali na odlišný rozsah zachovaného textu ve vymezené skupině rukopisů. Rukopisná znění modlitby lze podle úplnosti textu rozdělit na znění úplná a na znění zachovaná fragmentárně. Již dříve (Čajka 2013, 46-47) jsme z tohoto důvodu vymezili

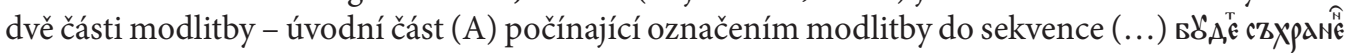
(KB 12/1089 141b 23 - 142a 10) a jádro modlitby (B), které je označeno v některých rukopisech

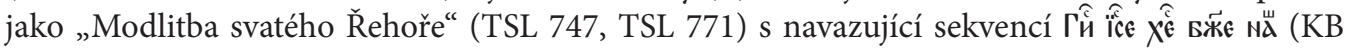
12/1089 142a 10sq) až do konce textu. Nejstarší relativně úplný rukopis Bes, rukopis Pogodinský (Pogod) ze 13. století, obsahuje text modlitby v rozsahu části A. Část modlitby, námi označovaná jako $\mathrm{B}$, není v rukopise Pogod doložena z důvodu mechanického poškození (chybí příslušné folio 
s navazujícím textem). Znění modlitby podle rukopisu TSL 771 je odrazem výběru textu (pouze část $\mathrm{B})$ ruským písařem.

Rukopis KB 12/1089 zachycuje z hlediska rozsahu textu Molitvu o izbavljenii otz bloda v podobě úplné.

\begin{tabular}{|l|l|l|}
\hline & úplnost textu & označení rukopisů \\
\hline $\begin{array}{l}\text { Rukopisy s úplným } \\
\text { textem }\end{array}$ & A+B & $\begin{array}{l}\text { Euch, Q, Synod, Synod 992, TSL 277, } \\
\text { TSL 747, KB 12/1089 }\end{array}$ \\
\hline $\begin{array}{l}\text { Rukopisy doložené } \\
\text { fragmentárně }\end{array}$ & A & Pogod \\
\cline { 2 - 3 } & B & TSL 771 \\
\hline
\end{tabular}

\section{Označení modlitby v rukopise KB 12/1089}

Př́slušnost ke skupině samostatně zapsaných textů modlitby ruské provenience dokládá v rukopi-

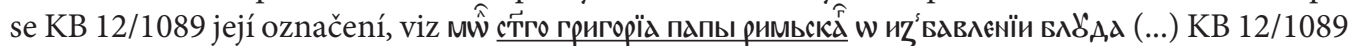
141b 23 - 142a 1. Připsání modlitby papeži Řehoři Velikému je velmi pravděpodobně odrazem povědomí prvních opisovačů o souvislosti s textem Bes, z jehož rukopisu byla na Rusi původně přepsána. ${ }^{21} \mathrm{~V}$ pozdějším období př̀edstavuje výskyt „řehořovské“ dedikace výraz ruské písařské tradice. Podobný způsob dedikace obsahují všechny dosud známé texty samostatně zapsané modlitby, a to bud' jako součást názvu modlitby (srov. KB 12/1089, TSL 277), nebo jako úvodní text druhé části modlitby (TSL 747, TSL 771). Srov.:

TSL 277

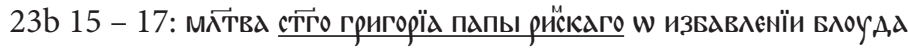

TSL 747

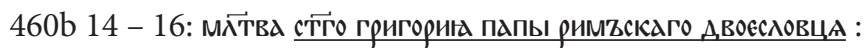

TSL 771

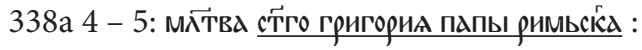

Lze tedy konstatovat, že se v tomto bodě řadí rukopisné znění KB 12/1089 do skupiny samostatných zápisů modlitby ve sbornících, přičemž se textově shoduje se zněním rukopisu TSL 277.

Text KB 12/1089 (spolu s dalšími rukopisy skupiny samostatných zápisů) zřetelně dokládá odkazem k autorství papeže Řehoře Velikého př́slušnost ke znění Molitvy o izbavljenii otr bloda reprezentovaného ruskými rukopisy (Pogod, Q, Synod, Synod 992, TSL 277, TSL 747, TSL 771).

\section{Příslušnost znění modlitby KB 12/1089 k ruské tradici textu}

Jelikož byly textové varianty zpracovány v kritickém aparátu edice in extenso, uvedeme pouze několik ilustrativních dokladů, které svědčí pro zařazení znění modlitby v rukopise KB 12/1089 do okruhu textů ruské tradice.

${ }_{21}$ Viz Čajka $(2013,51)$. Této skutečnosti si povšiml již A. I. Sobolevský, který upozornil v této souvislosti na rukopis TSL 747, srov. Sobolevskiy $(1906,13)$, Sobolevskiy $(1910,104)$. 
Pro snazší orientaci uvádíme $\mathrm{v}$ části textových variant odkaz na př́slušné místo textu $\mathrm{v}$ rukopisu KB 12/1089 (v jiných případech se až na výjimky odkazy neuvádí, nebot texty ostatních rukopisů této krátké památky byly edičně zpracovány). Transpozice slovosledné, hláskoslovné či morfologické nejsou v tomto smyslu textologicky relevantní, a proto je ponecháváme bez dalšího komentáře. Uvedený materiál však představuje zajímavý doklad vývoje textu modlitby v ruském prostředí.

1. и w сохраненїи з рака вйठннаго КB 12/1089 142a 2, Q, Synod, Synod 992, w схранении зрака

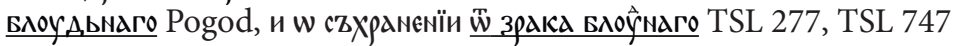

$\mathrm{X}$

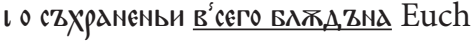

2. и и ш помышлємїд сложна KB 12/1089 142a 2sq, Pogod, Q, Synod, Synod 992, TSL 277, TSL 747

$\mathrm{X}$

deest in Euch

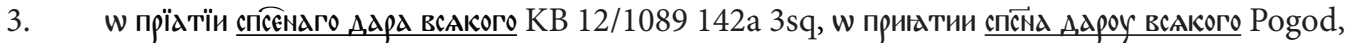
W ПРИАТИИ СПС̈НАГО ААРУ ВСАКОГО Q, TSL 277, W ПрИНАТИИ СПСТАЬНАГО ААРОУ ВСАКОГО TSL 747, приАт̈їа спасенаго дароY всакого Synod, Synod 992

$\mathrm{X}$

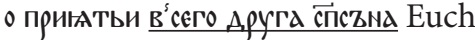

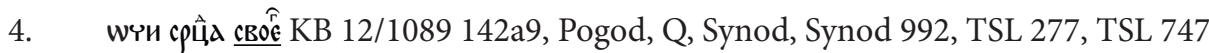

$\mathrm{x}$

очи срцц си Euch

5. єдинородныи KB 12/1089 142a 11, Q, Synod, Synod 992, TSL 747, TSL 771, єдинорйне sic TSL 277

$\mathrm{X}$

EА,ИМОЧААЫ Euch

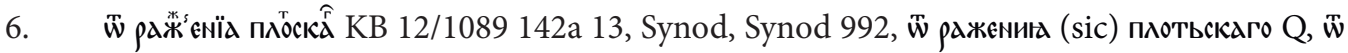

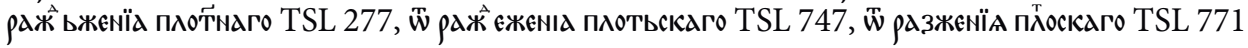
$\mathrm{x}$

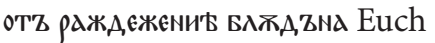

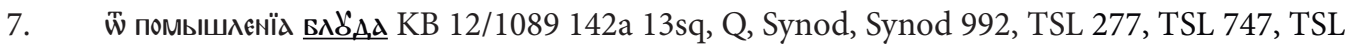
771

$\mathrm{x}$

ОТЪ ПОМZІШАЕни' БАХАДНА Euch

8. и оумышленїд сложна KB 12/1089 142a 14sq, Q, Synod, Synod 992, TSL 277, TSL 747, TSL 771

$\mathrm{x}$

deest in Euch 


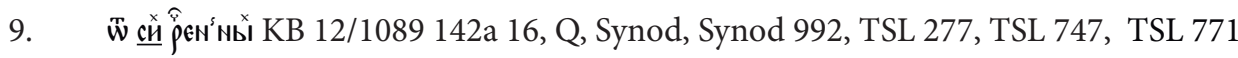
$\mathrm{X}$

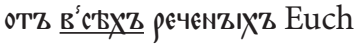

10. ne оугодно KB 12/1089 142a 17, Q, Synod, Synod 992, TSL 277, ne оугодны TSL 747, и не OYГO,ANO TSL 771 $\mathrm{X}$ вZ годинж Euch

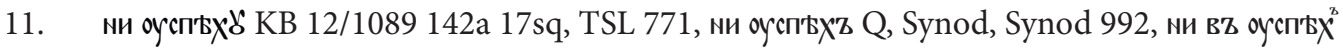
TSL 227, TSL 747

\section{$\mathrm{X}$}

Na cп'bXz Euch

12. ни сраменz KB 12/1089 142a 20sq, Q, Synod, Synod 992, TSL 771, пи посрамленz TSL 277, ни срамїє TSL 747

$\mathrm{x}$

deest in Euch

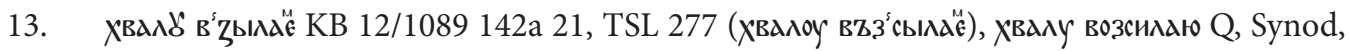
Synod 992, TSL 747, хвдлоу вZзсылдемZ to TSL 771

$\mathrm{x}$

ХвАлZІ вZ3А,АІа Euch

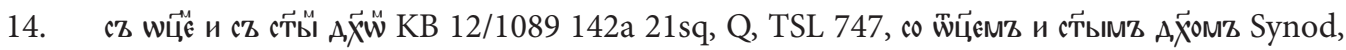
Synod 992, TSL 277, TSL 771

$\mathrm{x}$

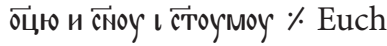

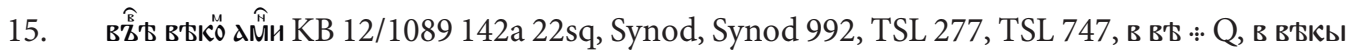

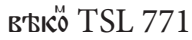

$\mathrm{X}$

deest in Euch

Soubor představených textových variant dokládá již dřive uvedenou dvojí textovou tradici Molitvy o izbavljenii otr bloda. Různočtení rukopisu KB 12/1089 jsou součástí shodných či velmi blízkých znění ruských rukopisů. $\mathrm{Z}$ tohoto důvodu hodnotíme text modlitby podle znění rukopisu $\mathrm{KB}$ 12/1089 jako součást ruské textové tradice s tím, že nově zpracovaný materiál potvrzuje předpoklad společného (hyp)archetypu textů ruského původu.

\section{Specifické doklady}

V této části práce poukážeme na dva textologicky specifické doklady, které nejsou v dosud známých rukopisech ruské tradice modlitby doloženy. V prvním př́ípadě se jedná o zřejmou písařskou chybu, v případě druhém poukážeme na zajímavou shodu se zněním Euch. 


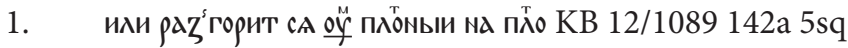

$\mathrm{X}$

или разгоритZ са оудZ плотныи на плоть Q, Synod, Synod 992, TSL 277, или разгорить са оудZ плотны на плотны TSL 747, или разгорить са оудZ плZть на плZть Pogod

$\mathrm{X}$

Аи разоритZ са (sic) емоу пльтьнад ПлZть Euch

Odhlédneme-li od evidentní chyby v zápise oymz (místo očekávaného oyaz), zápis KB 12/1089 odpovídá doslovně znění v Q, Synod, Synod 992, TSL 277.

2. deest in KB 12/1089 (cf. 142a 13), Euch

$\mathrm{x}$

и ӝ зрака вауданаго Q 112a 14sq, Synod, Synod 992, TSL 277, TSL 747, TSL 771

Dva rukopisné záznamy, které jsou zachovány v Euch a KB 12/1089, neobsahují text и w влуданаго (srov. Q 112a 14sq). Příslušná část textu je s výjimkou rukopisu KB 12/1089 součástí všech dalších rukopisů ruské provenience. Jelikož je uvedená shoda rukopisu KB 12/1089 s Euch ojedinělá, nelze z ní patrně vyvozovat podstatnější závěry. Není ale možné vyloučit ani to, že se v př́padě textu KB 12/1089 může jednat i o písařem vynechané místo (at už z jakýchkoliv důvodů) či opomenutí textu při zápisu, čímž by vznikl tento raritní textový paralelismus.

\section{Závěr}

Paraliturgický text Molitvy o izbavljenii otz bloda je doložen ve dvou textových tradicích, které vycházejí ze společného archetypu (původem patrně velkomoravského). Dvě vývojové linie textu modlitby jsou reprezentovány na jedné straně textem zapsaným v Euchologiu sinajském, na straně druhé početněji zastoupenou skupinou textů zachovaných v ruském prostředí.

Z výsledků materiálového srovnání s vymezenou skupinou dalších relevantních textů vyplývá, že text modlitby podle znění ruskocírkevněslovanského rukopisu KB 12/1089 pocházejícího ze třetí čtvrtiny 16. století představuje znění úplné a patří do ruské textové tradice. Označení Molitvy o izbavljenii otz bloda jako modlitby „řehořovské“ ukazuje jednak na souvislost s dalšími samostatně zapsanými texty památky v ruském prostředí (TSL 277, TSL 747, TSL 771), jednak rukopisně potvrzuje předpoklad přejetí textu modlitby $\mathrm{z}$ rukopisů Besěd na evangelije.

\section{REFERENCES}

\section{Primary sources}

Étaix, Raymond (ed.). 1999. Gregorius Magnus, Homiliae in Evangelia. Corpus Christianorum. Series Latina 141. Turnhout.

Konzal, Václav (ed.). 2005. Čtyřicet homilií Řehoře Velikého na evangelia v českocírkevněslovanském překladu, Díl první (Sancti Gregorii Magni pontificis XL homiliarum in Evangelia. In versione bohemo-slavonica, pars prima). Homilie I-XXIV. Praha. 
Konzal, Václav (ed.). 2006. Čtyřicet homilií Řehoře Velikého na evangelia v českocírkevněslovanském překladu, Díl druhý (Sancti Gregorii Magni pontificis XL homiliarum in Evangelia. In versione bohemo-slavonica, pars altera). Homilie XXV-XL. Praha.

Migne, Jacques Paul (ed.). 1849. Patrologiae cursus completus, series prima. Tomus 76. Parisiis 1849, col. 1071-1312.

Nahtigal, Rajko (ed.). 1941. Euchologium sinaiticum. Starocerkvenoslovanski glagolski spomenik. I. del. Fotografski posnetek. Ljubljana.

Nahtigal, Rajko (ed.). 1942. Euchologium sinaiticum. Starocerkvenoslovanski glagolski spomenik. II. del. Tekst s komentarjem, s prilogo posnetka prvega lista odlomka Sinajskega služebnika. Ljubljana.

Weiher, Eckhard et al. (eds.). 1998. Die Großen Lesemenäen des Metropoliten Makarij. Uspenskij spisok, 1.-11. März (Великие Минеи четьи митрополита Макария. Успенский список. 1-11 марта) [The Great Menaion Reader of Metropolitan Macarius of Moscow. The Uspenskii Manuscript, 1st - 11th March]. Monumenta linguae slavicae dialecti veteris, Fontes et dissertationes, tom XXXIX. Freiburg i. Br.

\section{Secondary sources}

Alekseev, Aleksey Ivanovich. 2012. Религиозные движения на Руси последней трети XIV начала XVI в. Стригольники и жидовствующие [Religious Movements in Russia in the Last Third of the 14th - Early 16th Century. Strigolniki and Judaizers]. Moscow.

Čajka, František. 2013. Molitva o izbavlenii otъ bluda v církevněslovanských rukopisech Trojickosergijevské lávry. In Slavia 82/1-2, 43-52.

Mareš, František Václav. 1963. Česká redakce církevní slovanštiny v světle Besěd Řehoře Velikého (Dvojeslova). In Slavia 32/3, 417-451.

Mareš, František Václav. 2000a. Česká redakce církevní slovanštiny v světle Besěd Řehoře Velikého (Dvojeslova). In Bláhová, Emilie - Vintr, Josef (eds.). Cyrilometodějská tradice a slavistika. Praha, 368-402.

Mareš, František Václav. 2000b. Církevněslovanské písemnictví v Čechách. In Bláhová, Emilie Vintr, Josef (eds.). Cyrilometodějská tradice a slavistika. Praha, 256-327.

Opis f. 351, 1985. Библиотека Кирилло-Белозерского монастыря. Опись. Фонд № 351. Публичная библиотека им. М. Е. Салтыкова-Щедрина. Отдел рукописей. [Library of the Kirillo-Belozersky Monastery. Description. Collection No. 351. Saltykov-Shchedrin Public Library. The Department of Manuscripts]. Leningrad. [Typescript].

Reinhart, Johannes. 1980. Methodisches zu den lexikalischen Bohemismen im TschechischKirchenslavischen am Beispiel der Homilien Gregors des Großen. In Wiener Slavistisches Jahrbuch 26, 46-102.

Reinhart, Johannes. 2000. Die Textologie der kirchenslavischen Übersetzung der Evangelienhomilien Gregors des Grossen. In Voss, Christian - Warkentin, Heide - Weiher, Eckhard (eds.). Abhandlungen zu den grossen Lesemenäen des Metropoliten Makarij. Band 1. Freiburg i. Br., 245-295.

Sobolevskiy, Aleksey Ivanovich. 1900. Церковно-славянские тексты моравского происхождения [Church Slavonic Texts of Great Moravian Origin]. Русский Филологический Вестник. Т. XLIII/1-2 [Russian Philological Bulletin. Vol. 43/1-2], Warsaw, 150-217 (samostatný prretisk Varšava 1900).

Sobolevskiy, Aleksey Ivanovich. 1906. К хронологии древнейших церковно-славянских памятников [To the Chronology of the Oldest Church Slavonic Texts]. In Известия 
Отделения Русского Языка и Словесности Императорской Академии Наук [News of the Department of Russian Language and Literature of the Imperial Academy of Sciences] 11/2, 1-19.

Sobolevskiy, Aleksey Ivanovich. 1910. Материалы и исследования в области славянской филологии и археологии, III. Словарный материал для двух древних памятников чешского происхождения [Materials and Research in the Field of Slavonic Philology and Archeology, III. Dictionary Material of Two Ancient Texts of Czech Origin]. Сборник Отделения русскаго языка и словесности (ОРЯС). LXXXVIII/3 [Proceedings of the Department of Russian Language and Literature. 88/3], St. Petersburg 1910.

Stroyev, Pavel Mikhaylovich. 1827. Второе прибавление к описанию славяно-российских рукописей, хранящихся в библиотеке тайного советника, сенатора, двора его императорского величества действительного каммергера и кавалера графа Федора Андреевича Толстова [The Second Addition to the Description of the Slavonic and Russian Manuscripts Kept in the Library of the Privy Councillor, Senator and Chamberlain of his Imperial Highness' Court, Count Fyodor Andreevich Tolstov]. Moscow.

Temchin, Sergey Yur'yevich. 2016. Еще один ранний (чешский) церковнославянский перевод с латыни: канон римского папы Григория I Великого из Лжеисидоровых декреталий в древнерусском трактате „Власфимия“ [Another Early (Czech) Church Slavonic Translation from Latin: The Canon of the Roman Pope Gregory I the Great of The PseudoIsidorian Decretals («False Decretals») in the Old Russian Treatise „Blasphemy“]. In Ангушева, Аделина et al. (eds.). Vis et sapientia: studia in honorem Anisavae Miltenova. Нови извори, интерпретации и подходи в медиевистиката [New Sources, Interpretations and Approaches in Medievistics]. София, 471-478.

Vepřek, Miroslav. 2008. Čtyřicet homilií Řehoře Velikého na evangelia v českocírkevněslovanském překladu. In Slavia 77/4, 443-445.

Vepřek, Miroslav. 2010. Filologický pohled na problém kontinuity cyrilometodějské kulturní tradice v Čechách 10. - 11. století. In Konštantínove listy [Constantine’s Letters] 3, 39-48.

Vepřek, Miroslav. 2014. Staroslověnské paraliturgické památky velkomoravského a českého původu. In Kouřil, Pavel et al. (eds.). Cyrilometodějská misie a Evropa - 1150 let od př́íchodu soluňských bratř́i na Velkou Moravu. Brno, 268-271.

Veprek, Miroslav. 2015. Prefix ${ }^{\star}(\mathrm{j}) \mathrm{bZ}$ - as a Component of Lexical Bohemisms in Church Slavonic? In Janyšková, Ilona - Karlíková, Helena (eds.). Etymological research into Old Church Slavonic. Proceedings of the Etymological Symposium Brno 2014, 9-11 September 2014, Brno. Praha, 423-430.

Vershinin, Konstantin Vladimirovich. 2015a. Цитаты из Бесед Григория Великого на Евангелие в Мериле Праведном и его литературном окружении [Quotations from Gospel Homilies by St Gregory the Great in Merilo Pravednoye («The Just Measure») and Its Literary Environment]. In Slavia 84/4, 402-408.

Vershinin, Konstantin Vladimirovich. 2015b. Правило черноризцем: к изучению связи Мерила Праведного с Кормчей русской редакции [The Monastic Rule: to Study the Connection of Merilo Pravednoye («The Just Measure») and Kormchaya Kniga («Nomocanon») of the Russian Redaction]. In Древняя Русь. Вопросы медиевистики [Ancient Russia. Questions of Medieval Studies], 2, 36-48.

Vershinin, Konstantin Vladimirovich. 2017. Об одном источнике Мерила Праведного и Кормчей [About One Source of Merilo Pravednoye («The Just Measure») and Kormchaya Kniga («Nomocanon»)]. In Древняя Русь. Вопросы медиевистики [Ancient Russia. Questions of Medieval Studies], 1, 5-8. 
Yegorova, Marina Sergeyevna. 2004. Русские аскетические сборники XIV-XVI вв. как тип сборника [Russian Ascetic Collections of the 14th - 16th Centuries as a Type of Collection]. In Труды Отдела древнерусской литературы. Т. 56 [Proceedings of the Department of Old Russian Literature. Vol. 56], St. Petersburg, 181-234.

Zema, Valeriy Yevgenovich. 2007. Папа Григорій Великий у лабетах легенд та історіографії [Pope Gregory the Great in the Paws of Legends and Historiography]. In Український історичний журнал [Ukrainian Historical Magazine] 1, 20-39.

\begin{abstract}
SUMMARY: MOLITVA O IZBAVLENII OT BLUDA IN THE MANUSCRIPT KB 12/1089. Molitva o izbavljenii otz bloda (and also Slovo bolęštiichs radi) is paraliturgical text which is preserved in Old Church Slavonic manuscript (Euchologium Sinaiticum). The prayer is also written to Russian Church Slavonic manuscripts, which contain Forty Gospel Homilies by Pope Gregory the Great (Besědy na evangelije). The third group of records represents texts that are individually registered in the Russian Church Slavonic manuscripts. Textological comparison and their title („St Gregory's the Great Prayer"), show clear connection with the source of their text - codexes Church Slavonic Forty Gospel Homilies by Pope Gregory the Great (Besédy na evangelije). So far known manuscripts of the Molitva o izbavljenii otz bloda represent Old Church Slavonic and Russian group. The close relationship of known manuscript versions of the prayer in manuscripts of Czech Church Slavonic Forty Gospel Homilies by Pope Gregory the Great (Besědy na evangelije) and in the ancient Euchologium Sinaiticum strongly reinforces the hypothesis of the Great Moravian origin of their common archetype. The occurrence of the prayer as an ancient, perhaps text of the Great Moravian origin, and as an integral part of the Czech Church Slavonic Forty Gospel Homilies by Pope Gregory the Great (Besédy na evangelije) leads some scholars to the hypothesis that this prayer was (as Great Moravian heritage) part of the Old Church Slavonic literature in Prremyslid Bohemia in the 10th - 11th century. The presented study deals with the text of prayer on the basis of the previously unknown manuscript from the Kirillo-Belozersky Monastery from the third quarter of the 16th century. The text of the prayer is preserved in a Russian Church Slavonic manuscript (National Library of Russia, Sankt-Peterburg) with signature KB 12/1089. The character of the text and textual comparison with other already known texts of the prayer shows that the prayer KB 12/1089 is Russian Church Slavonic version of the prayer and is part of the textological group of the Russian provenance. An integral part of the study is also the edition of the Molitva o izbavljenii ots bloda (KB 12/1089) and the apparatus criticus, which is based on the text of all known (edited) manuscripts of the prayer. The hypothesis about the possible Great Moravian origin of the prayer and Czech mediation during its transfer to the Russian environment remains valid.
\end{abstract}

PhDr. František Čajka, Ph.D.

Jan Evangelista Purkyně University in Ústí nad Labem

Faculty of Education

České mládeže 8

40096 Ústí nad Labem

Czech Republic

frantisek.cajka@email.cz 